\title{
Targeting $\$ 1$ integrin restores sensitivity to docetaxel of esophageal squamous cell carcinoma
}

\author{
RYOTA MORI, HIDEYUKI ISHIGURO, YOSHIYUKI KUWABARA, MASAHIRO KIMURA, \\ AKIRA MITSUI, KEISUKE TOMODA, YOICHIRO MORI, RYO OGAWA, \\ TAKEYASU KATADA, KOSHIRO HARATA and YOSHITAKA FUJII \\ Nagoya City University Graduate School of Medical Sciences, Oncology, \\ Immunology and Surgery, 1 Kawasumi, Mizuho-cho, Mizuho-ku, Nagoya 467-8601, Japan
}

Received July 31, 2008; Accepted September 1, 2008

DOI: 10.3892/or_00000150

\begin{abstract}
Esophageal squamous cell carcinoma (ESCC) is a common and highly fatal cancer in Japan. Systemic chemotherapy is used, but some tumors show resistance to it. The mechanisms of tumor resistance to chemotherapy remain largely unknown. We determined the chemosensitivity of 15 ESCC cell lines (TE-1-5, TE-8-15, KYSE140 and KYSE150) to docetaxel by clonogenic and MTT assays. We used cDNA microarray analysis and quantitative RT-PCR to determine which genes might determine resistance to docetaxel. Small interfering RNA (siRNA) was used to suppress gene expression and its effect on the chemosensitivity of the cell was determined. The cell line with the most resistance to docetaxel was TE-2. Using microarray analysis, we identified $\beta 1$ integrin (ITGB1) to be overexpressed in this cell line. Higher expression of ITGBI mRNA was significantly associated with docetaxel resistance $\left(\mathrm{n}=15, r^{2}=0.66, \mathrm{P}=0.0110\right)$. Suppression of ITGB1 expression using siRNA sensitized the TE-2 cells to docetaxel. These data suggest that overexpression of ITGB 1 may be related to resistance to chemotherapy and that targeting $I T G B 1$, particularly in patients on docetaxel therapy, may enhance the effect of chemotherapy in patients with ESCC.
\end{abstract}

\section{Introduction}

In Japan, $>11,000$ patients die of esophageal cancer every year, accounting for $\sim 3 \%$ of Japanese cancer deaths; esophageal cancer is the sixth highest cause of cancer death in Japanese males. The treatment of advanced esophageal squamous cell

Correspondence to: Dr Hideyuki Ishiguro, Nagoya City University Graduate School of Medical Sciences, Oncology, Immunology and Surgery, 1 Kawasumi, Mizuho-cho, Mizuho-ku, Nagoya 467-8601, Japan

E-mail: h-ishi@med.nagoya-cu.ac.jp

Key words: small interfering RNA, 31 integrin, docetaxel, esophageal squamous cell carcinoma carcinoma (ESCC) includes surgery, radiotherapy, chemotherapy, or more commonly a combined treatment regimen. Compared with radiotherapy alone, cisplatin-based chemoradiotherapy has been shown to improve the survival of patients with ESCC. Systemic chemotherapy has significantly reduced the incidence of distant metastasis and local recurrence, but its effect on overall survival has been less than satisfactory and newer drugs are currently being tested.

Docetaxel is a taxane that shows significant antitumor effects. It has shown clinical activity in a wide spectrum of solid tumors, including those of the breast, lung, ovary and prostate $(1,2)$. Data concerning the biological effects and mechanisms of docetaxel on ESCC cells in vitro and in vivo are limited.

Herein, we have used microarray analysis to identify that the gene $I T G B 1$, which encodes $I T G B 1$, was specifically overexpressed in the cell lines that showed resistance to docetaxel. Integrins are cell surface adhesion receptors composed of $\alpha$ and $\beta$ subunits; they mediate cell-extracellular matrix and cell-cell interactions (3). ITGB1 transduces biochemical signals from the extracellular environment, particularly those involved in growth, differentiation, invasiveness and metastatic potential of malignant cells $(4,5)$. Altered expression of integrins has been reported to be involved in tumor suppression and progression (6-8). Here, we report that ITGB1 expression might be related to tumor cell resistance to chemotherapy; thus, ITGB1 might provide a therapeutic target, particularly in patients on docetaxel.

\section{Materials and methods}

Docetaxel and cell lines. Docetaxel (Sanofi-Aventis) was suspended in RPMI-1640 (Sigma-Aldrich, St. Louis, MO) containing 10\% fetal bovine serum (FBS) (JRH Biosciences, Lenexa, KS). Serial dilutions were prepared to achieve final docetaxel concentrations of $0.05,5,1,2.5,5,10,25$ and $50 \mathrm{ng} / \mathrm{ml}$. The ESCC cell lines TE-1-5, TE-8-15, KYSE140 and KYSE150 were grown in RPMI-1640 containing 10\% FBS. Giemsa staining, clonogenicity assays and small interfering RNA (siRNA) transfection were performed at 70-80\% confluence.

Chemosensitivity. Cells were seeded into 96-well microtiter plates containing $100 \mu \mathrm{l}$ culture medium at a concentration of 
$1 \times 10^{4}$ cells/well. After $24 \mathrm{~h}$, the cells were treated with docetaxel at concentrations of $0.05,5,1,2.5,5,10,25$, and $50 \mathrm{ng} / \mathrm{ml}$. All dilutions were performed in the culture medium. The total volume within each well was brought to $200 \mu \mathrm{l}$ using growth medium and the plates were incubated at $37^{\circ} \mathrm{C}$ under $5 \% \mathrm{CO}_{2}$ for $72 \mathrm{~h}$. Further, $20 \mu \mathrm{l} /$ well of the cell proliferation reagent WST-1 (Roche Applied Sciences, Mannheim, Germany) was added to $200 \mu 1$ of the cell culture medium and held for $3 \mathrm{~h}$. The absorbance of the samples was measured at 450 and $690 \mathrm{~nm}$ using a bichromatic ELISA reader. Relative proliferation was defined as the ratio of absorption measured in the docetaxel-treated cells (A) to that in the untreated control cells (A0). All experiments were performed in triplicate. $\mathrm{IC}_{50}$ values were calculated from plots of drug concentration vs. the proportion of cells that survived.

Oligonucleotide microarray. In order to reduce experimental errors, a set of oligonucleotide microarray slides containing a duplicate set of 34,594 spots was used to analyze each expression profile. Total RNA was isolated using the RNeasy mini kit (Qiagen, Chatsworth, CA) and digested by RNasefree DNase I (Nippon Gene Co., Tokyo, Japan) according to the recommendations of the manufacturers. We then performed T7-based RNA amplifications and preparations of cDNA probes using $5 \mu \mathrm{g}$ of the total RNA, as described elsewhere $(9,10)$. Amplified RNA $(2.5 \mu \mathrm{g})$ from each cell line was labeled with Cy5-dCTP (Amersham Pharmacia Biotech, Uppsala, Sweden) and an equal amount of amplified RNA from a pool of the total RNA of the normal human esophageal mucosa cell line Het-1A (Invitrogen, Carlsbad, CA) was labeled with Cy3-dCTP (Amersham Pharmacia Biotech). Hybridization, washing and scanning were performed as described elsewhere $(11,12)$. The intensity of each duplicated signal was evaluated photometrically using the ArrayVision computer program (Imaging Research, Inc., St. Catharines, Ontario, Canada). To normalize the mRNA in the cell lines, the $\mathrm{Cy} 5: \mathrm{Cy} 3$ ratio of each expressed gene was adjusted such that the mean Cy5:Cy3 ratio of Het-1A was 1.0. Subsequently, the duplicated spots on each slide were averaged $(9,11,12)$. In addition, a cut-off value for each expression level was automatically calculated by variance analysis and data with low signal intensities were excluded from further investigation.

Quantitative real-time polymerase chain reaction ( $q R T$ $P C R)$. Total RNA $(2 \mu \mathrm{g})$ was converted to cDNA using the GeneAmp RNA PCR core kit (Applied Biosystems, Tokyo, Japan), according to the manufacturer's instructions. qRTPCR amplification of the cDNA template corresponding to 20 ng of total RNA was performed using Taq Man PCR Universal PCR Master Mix (Applied Biosystems, Foster City, CA) in an ABI PRISM 7500 sequence detection PCR system (Applied Biosystems). The PCR conditions were as follows: $50^{\circ} \mathrm{C}$ for $2 \mathrm{~min}$ and $95^{\circ} \mathrm{C}$ for $10 \mathrm{~min}$, followed by 40 cycles each of $95^{\circ} \mathrm{C}$ for $15 \mathrm{sec}$ and $60^{\circ} \mathrm{C}$ for $1 \mathrm{~min}$. ITGBI Taq Man probes were synthesized from sequences in exons 10, 11 and 12 (Assays-on-Demand Gene Expression System, ITGB1 assay ID: Hs00236976_m1; Applied Biosystems). Expression levels were normalized against glyceraldehyde-3-

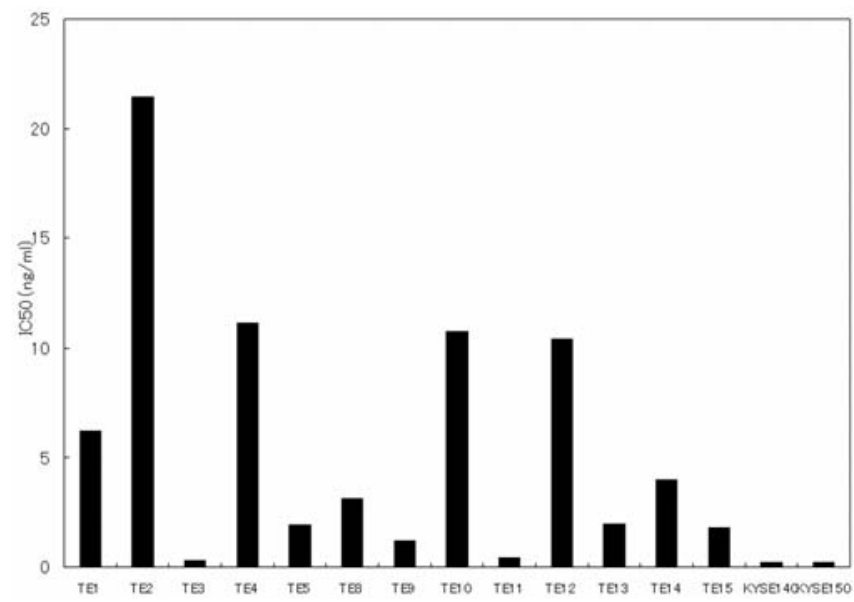

Figure 1. Docetaxel $\mathrm{IC}_{50}$ of 15 esophageal squamous cell carcinoma cell lines. Cells were exposed to graded dilutions of docetaxel and cell survival was determined using an MTT assay in triplicate; the mean of the assay values is shown.

phosphate dehydrogenase (Assays-on-Demand Gene Expression Systems, assay ID: Hs99999905_m1; Applied Biosystems).

Western blotting. Cells propagated in three-dimensional IrECM were first isolated with ice-cold phosphate-buffered saline/EDTA [0.01 mol/1 sodium phosphate ( $\mathrm{pH} 7.2)$ containing $138 \mathrm{mmol} / \mathrm{l}$ sodium chloride and $5 \mathrm{mmol} / \mathrm{l}$ EDTA]; then lysed in a radioimmunoprecipitation assay buffer. Equal amounts of protein were loaded onto reducing SDS gels. After transfer onto a nitrocellulose membrane (Invitrogen), blots were blocked with $5 \%$ non-fat milk and probed. Primary antibodies used include $I T G B 1$, clone 18 (1:2500; BD Transduction Laboratories, Lexington, KY), $\alpha$-PCNA (1:1,000; Santa Cruz Biotech, Santa Cruz, CA). Blots were washed, incubated with secondary antibody (Mouse IgG1) and exposed to X-rays.

siRNA transfection and cell proliferation assay. ITGBI siRNA (M-004506-00 Dharmacon, Lafayette, Co.) and control (siControl ${ }^{\mathrm{TM}}$ Non-targeting pool) transfections were performed using human T-cell nucleofector kits (Amaxa, Cologne, Germany) according to the manufacturer's instructions. The cells were seeded into 96-well plates in complete culture medium at a density of $5 \times 10^{4}$ cells/well. After $24 \mathrm{~h}$, medium was added with or without docetaxel $(0.05,5,1,2.5,5,10,25$ and $50 \mathrm{ng} / \mathrm{ml})$. After $72 \mathrm{~h}$, cell proliferation was assessed using an MTT assay (CellTiter 96; Promega, Madison, WI). Cell proliferation was determined as the ratio of the absorbance of docetaxel-treated cells to that of the control cells seeded with non-target siRNA. Each assay was performed in triplicate.

Statistical methods. The Graphcel software program was used to determine $\mathrm{IC}_{50}$ values. Statistical analyses were performed using the Mann-Whitney $U$ test for unpaired samples and Wilcoxon's signed rank test for paired samples. Linear relationships between variables were determined by 


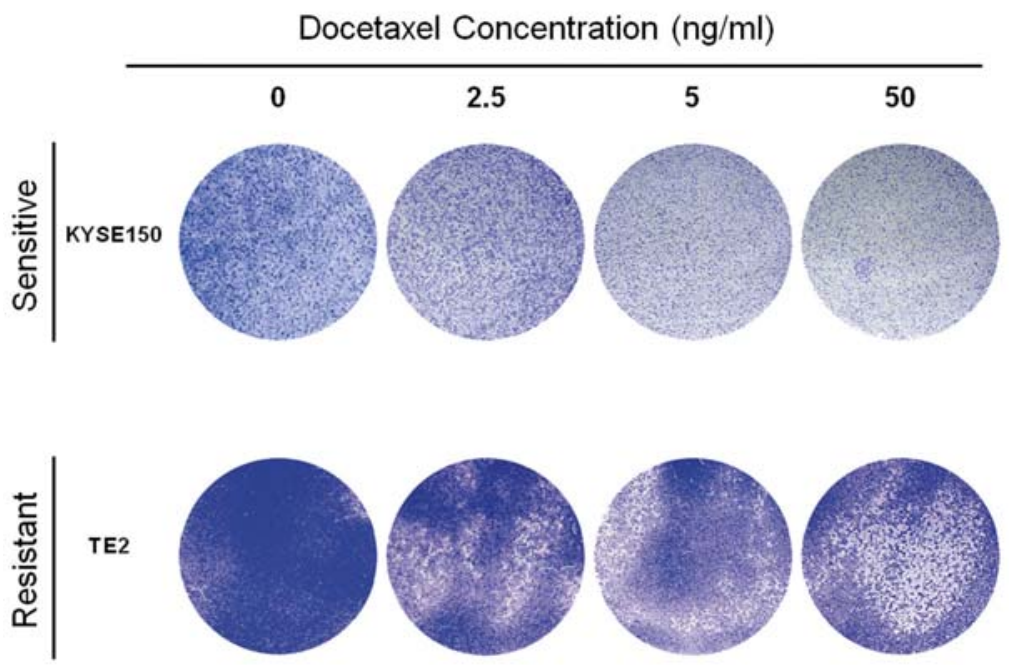

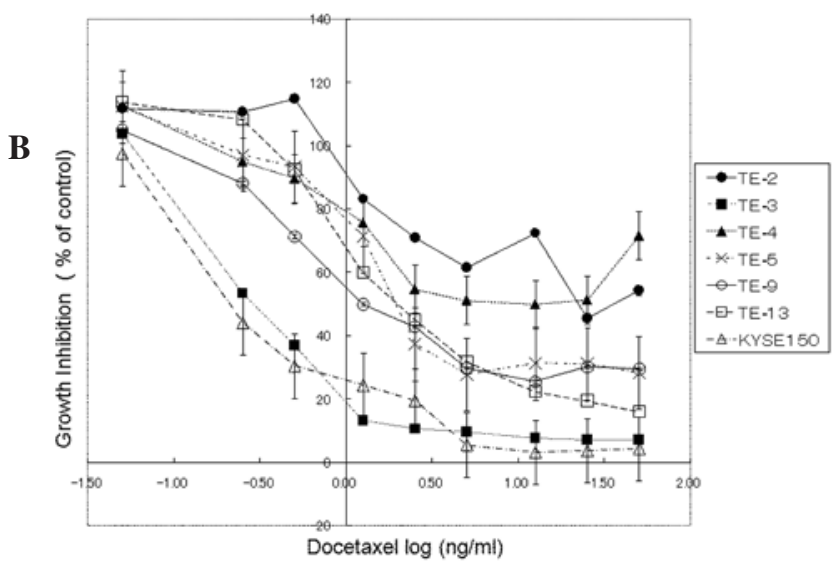

means of a simple linear regression. The StatView software package (Abacus Concepts Inc., Berkeley, CA) was used for all analyses and $\mathrm{P}<0.05$ was considered significant.

\section{Results}

Chemosensitivity of esophageal cancer cell lines to docetaxel. We used an MTT assay to determine the sensitivity $\left(\mathrm{IC}_{50}\right)$ of 15 esophageal cancer cell lines to docetaxel (Fig. 1).
Figure 2. The sensitivity of two esophageal squamous cell carcinoma cell lines to docetaxel (A) Cells were cultured in medium containing the indicated concentrations of docetaxel and cell viability was measured at $72 \mathrm{~h}$. Each well was stained with Giemsa. There were fewer colonies of the sensitive cell line (KYSE150) than the resistant cell line (TE-2) at docetaxel concentrations $>2.5 \mathrm{ng} / \mathrm{ml}$. Docetaxel $\mathrm{IC}_{50}$ of esophageal squamous cell carcinoma cell lines. (B) Cells were incubated with varying concentrations of docetaxel for $72 \mathrm{~h}$ and cell viability was determined using the MTT assay. The data shown are the mean (standard deviation) of triplicate cultures. The standard deviations were $<10 \%$ of the mean.

TE-2 was the most resistant cell line, followed by TE-4, TE-10, TE-12 and TE-1. Other cell lines showed moderate to high sensitivity $\left(\mathrm{IC}_{50}<5 \mathrm{ng} / \mathrm{ml}\right)$. The clonogenic potential of each cell line after docetaxel treatment varied and Fig. 2A illustrates two representative cell lines, the sensitive KYSE150 and the resistant TE-2. Fig. 2B shows the response of eight representative cell lines to varying concentrations of docetaxel measured in three separate experiments, each time in triplicate. Of the cell lines shown, three were sensitive (TE-3, KYSE140 and

B

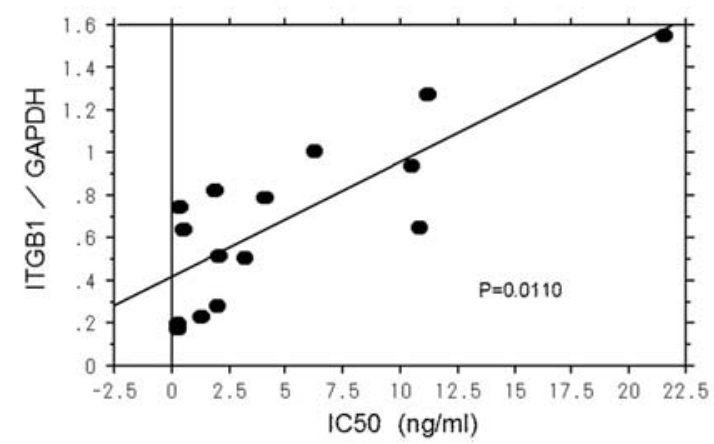

Figure 3. Expression of ITGBI mRNA in esophageal cancer cell lines and in a normal esophageal mucosal cell line, examined by quantitative RT-PCR. (A) Expression levels were normalized against glyceraldehyde-3-phosphate dehydrogenase (GAPDH). Correlation between ITGB1 mRNA expression and resistance to docetaxel in 15 esophageal cancer cell lines. (B) The cell line with the highest ITGB 1 mRNA expression showed the highest resistance to docetaxel. The correlation was significant $(\mathrm{P}=0.0110)$. 
Table I. Highly expressed genes.

\begin{tabular}{|c|c|c|c|c|c|}
\hline Gene name & Map & EMBL & Gene name & Map & EMBL \\
\hline EPLIN & $12 q 13$ & ВC010664 & CYB5-M & $16 \mathrm{q} 22.1$ & ВC004373 \\
\hline KRT6A & $12 q 12-q 13$ & L42599 & SLC25A4 & $4 q 35$ & ВC008664 \\
\hline DDX26 & 13q14.12-q14.2 & AF097645 & PERLD1 & $17 q 12$ & AF217980 \\
\hline IFNA2 & $9 \mathrm{p} 22$ & A04970 & C14orf124 & $14 q 11.2$ & AF226050 \\
\hline KRT5 & $12 q 12-q 13$ & M19723 & DXYS155E & $\mathrm{Xp} 22.32$ & M99578 \\
\hline DDR2 & $1 q 12-q 23$ & X74764 & GOLPH2 & $9 q 21.33$ & \\
\hline \multicolumn{6}{|l|}{ AK075542 } \\
\hline KISS1 & $1 \mathrm{q} 32$ & AY117143 & FLJ20308 & $17 \mathrm{p} 11.2$ & \\
\hline \multicolumn{6}{|l|}{ AK000315 } \\
\hline TM4SF1 & $3 q 21-q 25$ & ВC010166 & S100P & $4 \mathrm{p} 16$ & ВС006819 \\
\hline KRT6IRS & $12 q 13.13$ & AJ308599 & RP42 & $3 q 26.3$ & AF456425 \\
\hline HMS & 11q14.1-q14.3 & & RGS2 & $1 q 31$ & ВС007049 \\
\hline S100A2 & $1 \mathrm{q} 21$ & BC002829 & C17orf37 & $17 \mathrm{q} 12$ & ВC006006 \\
\hline DSC3 & $18 q 12.1$ & AF293359 & GPR110 & $6 \mathrm{p} 12.3$ & \\
\hline \multicolumn{6}{|l|}{ AK026337 } \\
\hline $\mathrm{CD} 44$ & $11 \mathrm{p} 13$ & AY101193 & TFDP2 & $3 q 23$ & U35117 \\
\hline CAV1 & 7q31.1 & ВС009685 & NCOR1 & $17 \mathrm{p} 11.2$ & AB019524 \\
\hline DST & $6 \mathrm{p} 12-\mathrm{p} 11$ & U04850 & PAPSS2 & 10q23-q24 & ВС009894 \\
\hline KRT5 & 12q12-q13 & M19723 & DAF & $1 q 32$ & \\
\hline \multicolumn{6}{|l|}{ AY055759 } \\
\hline COL17A1 & $10 q 24.3$ & AL138761 & QSCN6 & $1 q 24$ & U97276 \\
\hline SFN & $1 \mathrm{p} 36.11$ & ВC023552 & PDCD8 & $\mathrm{Xq} 25-\mathrm{q} 26$ & AF131759 \\
\hline RPS7 & $2 \mathrm{p} 25$ & X56846 & HPGD & $4 q 34-q 35$ & J05594 \\
\hline BMP7 & $20 q 13$ & ВC004248 & ALOX15B & $17 \mathrm{p} 13.1$ & AF468052 \\
\hline TMEM40 & $3 p 25.2$ & AK092470 & HSPC171 & $16 q 22.1$ & ВC003080 \\
\hline CTSC & 11q14.1-q14.3 & U79415 & CLDN1 & $3 q 28-q 29$ & BC012471 \\
\hline RBPMS & 8p12-p11 & D84111 & C14orf 147 & $14 q 13.1$ & BC016805 \\
\hline COL5A2 & $2 q 14-q 32$ & M11718 & MANSC1 & $12 \mathrm{p} 13.2$ & \\
\hline \multicolumn{6}{|l|}{ AK023622 } \\
\hline ERBB2 & 17q11.2-q12 & X03363 & C11orf2 & $11 \mathrm{q} 13$ & ВC017438 \\
\hline AGR2 & $7 \mathrm{p} 21.3$ & AF115926 & BENE & $2 q 13$ & U17077 \\
\hline NMU & $4 q 12$ & ВС012908 & FLII & $17 \mathrm{p} 11.2$ & U01184 \\
\hline KRT7 & $12 q 12-q 13$ & ВC002700 & DUSP6 & $12 q 22-q 23$ & ВC037236 \\
\hline C14orf135 & $14 q 23.1$ & ВC033843 & BAG1 & $9 \mathrm{p} 12$ & AF116273 \\
\hline AKAP13 & $15 q 24-q 25$ & AB055890 & LY6D & 8q24-qter & U66837 \\
\hline YME1L1 & $10 \mathrm{p} 14$ & ВC007795 & ITGB 1 & $10 \mathrm{p} 11.2$ & U33881 \\
\hline PTGES & $9 q 34.3$ & ВС008280 & LCN2 & $9 q 34$ & S75256 \\
\hline
\end{tabular}

KYSE150), four were resistant (TE-2, TE-4, TE-10 and TE-12) and the remaining eight cell lines exhibited intermediate sensitivity to docetaxel (Fig. 2B). TE-2 was the most resistant to docetaxel $\left(\mathrm{IC}_{50}>20 \mathrm{ng} / \mathrm{ml}\right)$.

Microarray analysis of genes differentially expressed in cell lines sensitive or resistant to docetaxel. Next, a microarray analysis was performed in order to identify the genes whose expression may confer resistance to docetaxel. Total RNA was extracted from each cell line and the reverse transcriptase reaction was carried out. Table I shows the genes whose expression was high in the docetaxel-resistant TE-2 cell line and low in the other cell lines. We focused on ITGBI for further analysis.

Expression of ITGB1 in esophageal cancer cell lines and its relationship with docetaxel sensitivity. We examined ITGBI mRNA expression in the 15 cell lines and in the normal human esophageal mucosa cell line Het-1A by quantitative PCR. ITGB1 expression was found to be higher in many esophageal cancer cell lines than in Het-1A. ITGB1 mRNA expression was very high in TE-1, TE-2 and TE-4 (Fig. 3A). 
A

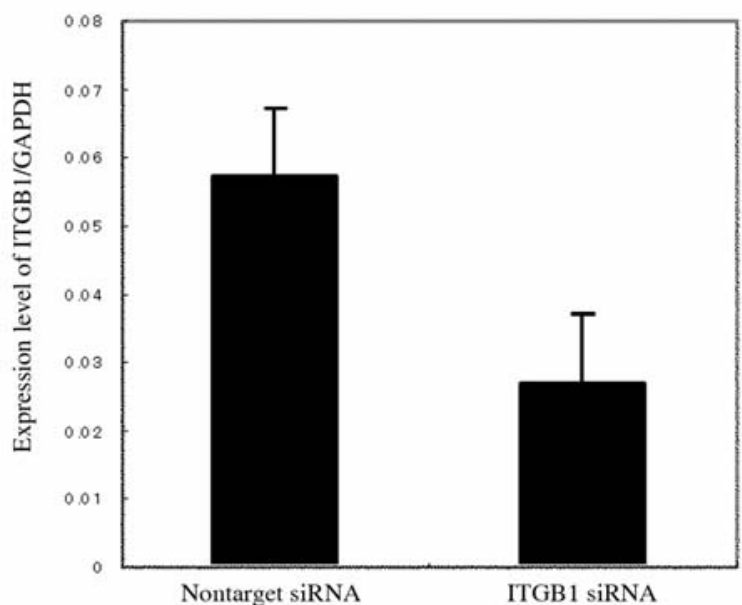

B

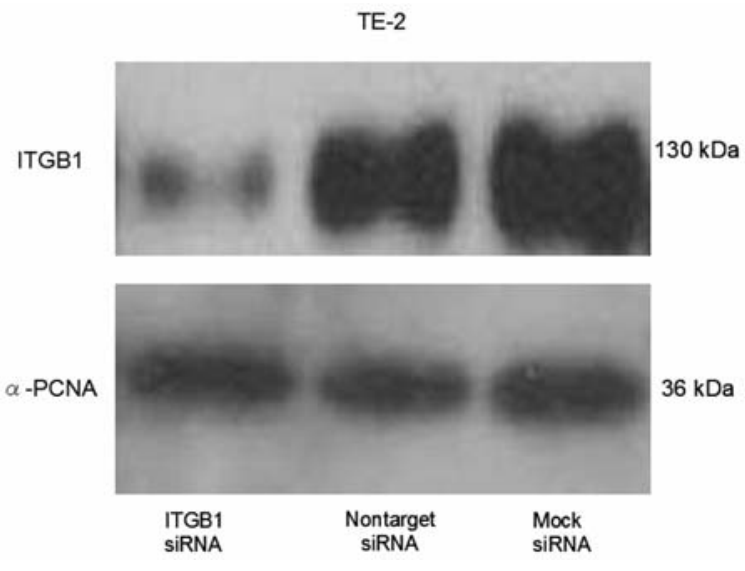

C

Concentration Docetaxel $(\mathrm{ng} / \mathrm{ml})$

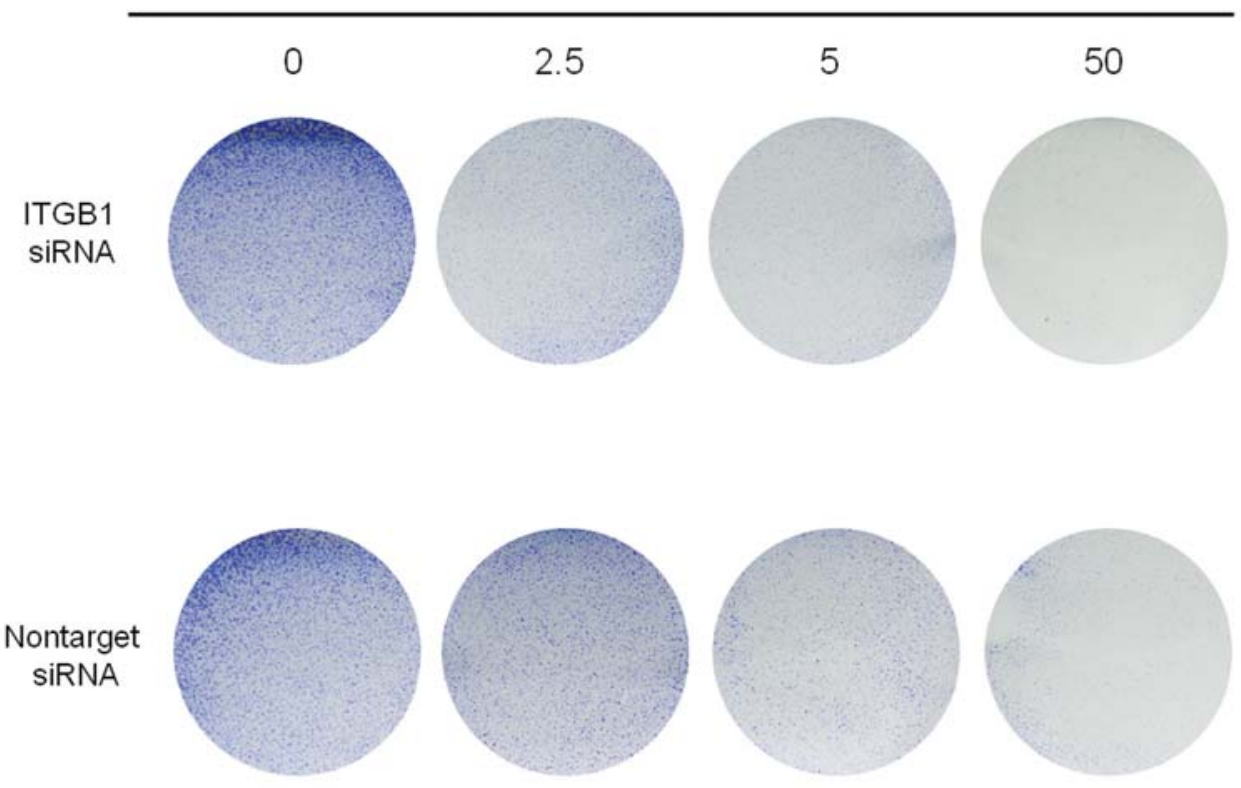

D

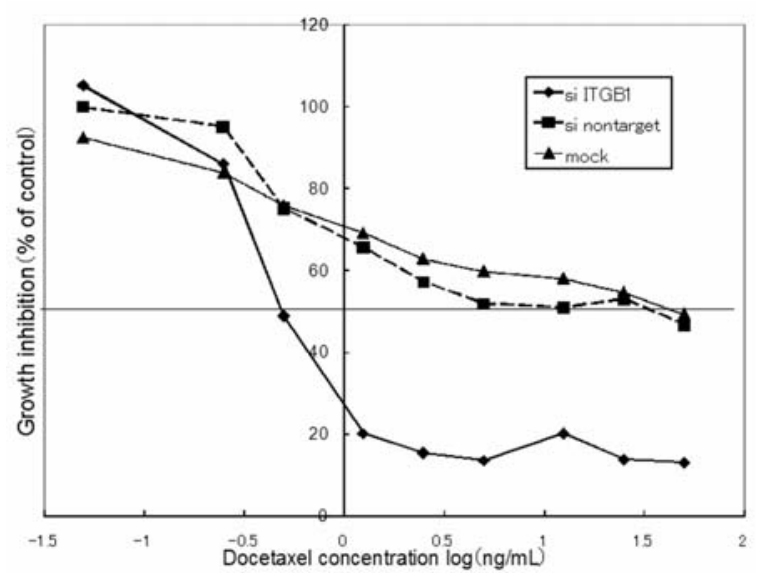

E

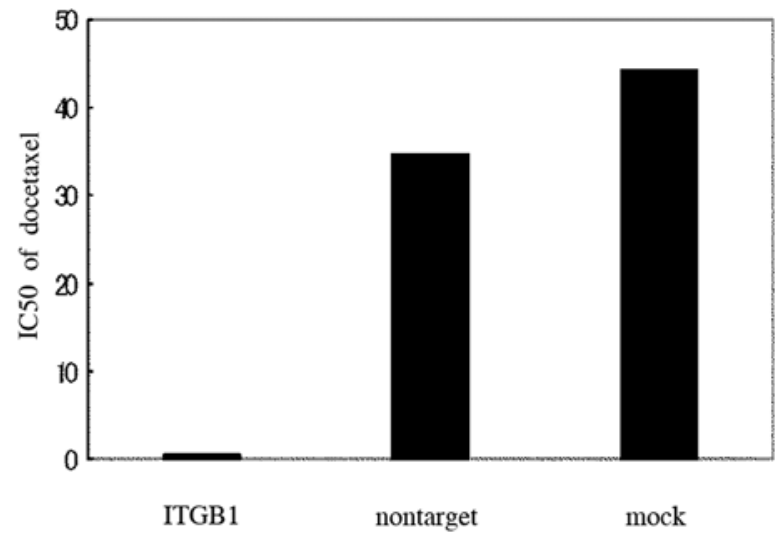

Figure 4. Expression of ITGBI mRNA in TE-2 was down-regulated by a siRNA. (A) Expression levels were measured by real-time RT-PCR. The mean and standard error of the triplicate assay are shown. Western blot analysis of ITGB1 protein expression in the siRNA-treated TE-2 cells. (B) siRNA of ITGB1 down-regulated the expression of ITGB1 protein in TE-2; however, it had little effect on $\alpha$-PCNA. Non-specific siRNA (non-target siRNA) or mock transfection (mock siRNA) had no effect. Sensitivity to docetaxel of TE-2 cells treated with siRNA of ITGB1. (C) Cells that were treated with siRNA of $I T G B 1$ or seeded with non-target siRNA were incubated with varying concentrations of docetaxel for $72 \mathrm{~h}$ and each well was stained with Giemsa. Sensitivity to docetaxel of TE-2 cells treated with siRNA of ITGB1. (D) Cells treated with or without the siRNA of ITGBI or non-target siRNA were incubated with varying concentrations of docetaxel for $72 \mathrm{~h}$ and cell viability was determined using an MTT assay. The data shown are the mean of triplicate cultures. The standard deviations were $<10 \%$ of the mean. (E) Docetaxel $\mathrm{IC}_{50} \mathrm{~s}$ of ESCC cell lines, calculated using the data shown in (D). Cells were exposed to varying concentrations of docetaxel. Cell survival was determined using the MTT assay. 
It was highest in the TE- 2 cell line, which was the most resistant to docetaxel. Regression analysis revealed a strong positive correlation between expression of ITGBI mRNA and docetaxel $\mathrm{IC}_{50}$ in ESCC cell lines. The coefficient of correlation was 0.813 (Fig. 3B).

Inhibition of ITGB1 restores chemosensitivity of esophageal cancer cells to docetaxel. We used the siRNA technique to down-regulate ITGB1 mRNA in the TE-2 cell line (Fig. 4A), which was chosen because it was the most resistant to docetaxel and had the highest expression of ITGB1. Western blotting proved that $I T G B 1$ protein level was also reduced by siRNA (Fig. 4B). The down-regulation of ITGBI had a pronounced effect on the sensitivity of the cell to docetaxel. At the same concentration of docetaxel, cells treated with ITGB1 siRNA had fewer colonies than cells treated with nontarget siRNA (Fig. 4C). This enhancement of sensitivity by siRNA of ITGB1 was further confirmed using the quantitative MTT assay (Fig. 4D). Fig. 4E shows that the $\mathrm{IC}_{50}$ of TE-2 cells treated with ITGB1 siRNA was significantly lower than untreated cells, as calculated from Fig. 4D.

\section{Discussion}

Despite the fact that many different chemotherapeutic agents and regimens have been developed to treat advanced ESCC, there has been no significant increase in patient survival. Therefore, novel chemotherapeutic strategies are necessary. Docetaxel is an antimicrotubulin agent that has antiproliferative and suppressive effects on cancer cells. It is known that in the basic mechanism, it binds to tubulin and disturbs the equilibrium between microtubule assembly and disassembly during mitosis (13). Stabilization of microtubules by docetaxel impairs mitosis and exerts an anticancer effect in tumors (13). In addition to its effects on microtubules, docetaxel also induces apoptosis with down-regulation of bcl-xL and bcl-2 and up-regulation of p21WAF1 and p53 (14,15). Integrins, heterodimeric transmembrane receptors composed of $\alpha$ and $\beta$ subunits, can be found in focal adhesions. In ESCC patients, no clear correlation has been demonstrated between tumor formation, invasion and ITGB1 expression. In mice, however, a crucial role of $I T G B 1$ in tumor formation and metastasis has been demonstrated. ITGBI is aberrantly expressed in human breast carcinomas and has been shown to play a central role in growth, apoptosis, invasion and metastasis (16-20). In addition to its role in cancer progression, an emerging body of evidence indicates that $I T G B 1$ signaling plays a significant role in mediating the resistance to cytotoxic chemotherapies by enhancing cell survival in hematologic, lung and breast malignancies (21-24). Inhibition of ITGB1 has also been shown to abolish metastasis in gastric and breast cancer models (25-28). Our results suggest that integrin signaling is an important survival pathway in cancer cells treated with docetaxel.

We have found here that ITGBI is specifically upregulated in an esophageal cell line with high resistance to docetaxel (Fig. 3A) and that ITGB1 mRNA expression positively correlates with docetaxel resistance (Fig. 3B). When ITGB1 expression was down-regulated using siRNA (Fig. 4A and B), cell sensitivity to docetaxel was apparently restored (Fig. 4D and E). These results indicate that expression of ITGB I may be an important determinant of the resistance of a cell to docetaxel.

It has previously been reported that ITGBI signaling is an important survival pathway in drug-induced apoptosis of breast cancer cells and that activation of this pathway may contribute to the development of drug resistance (21). There have been no previous studies of a relationship between $I T G B 1$ and esophageal cancer. We are also unaware whether $I T G B 1$ plays a role in cell response to other chemotherapeutic reagents, although the cell lines studied here showed distinct sensitivities to cis-diamminedichloride platinum (data not shown). The mechanisms by which ITGBl expression confers chemoresistance are unknown and future studies will aim to discover whether they are related to the function of integrins in cell adhesion. A complete understanding of the molecular events that mediate integrin-dependent survival of cancer cells may lead to new therapeutic tools for cancer treatment.

\section{Acknowledgements}

We would like to thank Mrs. Shinobu Makino for technical assistance.

\section{References}

1. Beer TM, El Geneidi M and Eilers KM: Docetaxel (taxotere) in the treatment of prostate cancer. Expert Rev Anticancer Ther 3: 261-268, 2003.

2. Hong WK: The current status of docetaxel in solid tumors. An MD Anderson Cancer Center Review. Oncology 16: 9-15, 2002.

3. Hynes RO: Integrins: versatility, modulation, and signaling in cell adhesion. Cell 69: 11-25, 1992.

4. Blau HM and Baltimore D: Differentiation requires continuous regulation. J Cell Biol 112: 781-783, 1991.

5. Juliano RL: The role of beta 1 integrins in tumors. Semin Cancer Biol 4: 277-283, 1993.

6. Dedhar S and Hannigan GE: Integrin cytoplasmic interactions and bidirectional transmembrane signaling. Curr Opin Cell Biol 8: 657-669, 1996.

7. Hemler ME, Mannion BA and Berditchevski F: Association of TM4SF proteins with integrins: relevance to cancer. Biochim Biophys Acta 1287: 67-71, 1996

8. Plath T, Detjen K, Welzel M, von Marschall Z, Murphy D, Schirner M, Wiedenmann B and Rosewicz S: A novel function for the tumor suppressor p16(INK4a): induction of anoikis via upregulation of the alpha(5)beta(1) fibronectin receptor. J Cell Biol 150: 1467-1478, 2000

9. Luo L, Salunga RC, Guo H, Bittner A, Joy KC, Galindo JE, Xiao H, Rogers KE, Wan JS, Jackson MR and Erlander MG: Gene expression profiles of laser-captured adjacent neuronal subtypes. Nat Med 5: 117-122, 1999.

10. Van Gelder RN, Von Zastrow ME, Yool A, Dement WC, Barchas JD and Eberwine JH: Amplified RNA synthesized from limited quantities of heterogeneous cDNA. Proc Natl Acad Sci USA 87: 1663-1667, 1990.

11. Kitahara O, Furukawa Y, Tanaka T, Kihara C, Ono K, Yanagawa R, Nita ME, Takagi T, Nakamura Y and Tsunoda T: Alterations of gene expression during colorectal carcinogenesis revealed by cDNA microarrays after laser-capture microdissection of tumor tissues and normal epithelia. Cancer Res 61: 3544-3549, 2001.

12. Ono K, Tanaka T, Tsunoda T, Kitahara O, Kihara C, Okamoto A, Ochiai K, Takagi $\mathrm{T}$ and Nakamura Y: Identification by cDNA microarray of genes involved in ovarian carcinogenesis. Cancer Res 60: 5007-5011, 2000.

13. Fulton B and Spencer CM: Docetaxel. A review of its pharmacodynamic and pharmacokinetic properties and therapeutic efficacy in the management of metastatic breast cancer. Drugs 51: 1075-1092, 1996. 
14. Avramis VI, Nandy P, Kwock R, Solorzano MM, Mukherjee SK, Danenberg P and Cohen LJ: Increased p21/WAF-1 and p53 protein levels following sequential three drug combination regimen of fludarabine, cytarabine and docetaxel induces apoptosis in human leukemia cells. Anticancer Res 18: 2327-2338, 1998.

15. Stein CA: Mechanisms of action of taxanes in prostate cancer. Semin Oncol 26: 3-7, 1999.

16. White DE, Kurpios NA, Zuo D, Hassell JA, Blaess S, Mueller U and Muller WJ: Targeted disruption of beta 1-integrin in a transgenic mouse model of human breast cancer reveals an essential role in mammary tumor induction. Cancer Cell 6: 159$170,2004$.

17. Berry MG, Gui GP, Wells CA and Carpenter R: Integrin expression and survival in human breast cancer. Eur J Surg Oncol 30: 484-489, 2004.

18. Gui GP, Wells CA, Yeomans P, Jordan SE, Vinson GP and Carpenter R: Integrin expression in breast cancer cytology: a novel predictor of axillary metastasis. Eur J Surg Oncol 22: 254-258, 1996.

19. Shaw LM: Integrin function in breast carcinoma progression. J Mammary Gland Biol Neoplasia 4: 367-376,1999.

20. Zutter MM, Krigman HR and Santoro SA: Altered integrin expression in adenocarcinoma of the breast. Analysis by in situ hybridization. Am J Pathol 142: 1439-1448, 1993.

21. Aoudjit F and Vuori K: Integrin signaling inhibits paclitaxelinduced apoptosis in breast cancer cells. Oncogene 20: 4995-5004, 2001.
22. Damiano JS: Integrins as novel drug targets for overcoming innate drug resistance. Curr Cancer Drug Targets 2: 37-43, 2002.

23. Lewis JM, Truong TN and Schwartz MA: Integrins regulate the apoptotic response to DNA damage through modulation of p53. Proc Natl Acad Sci USA 99: 3627-3632, 2002.

24. Sethi T, Rintoul RC, Moore SM, MacKinnon AC, Salter D, Choo C, Chilvers ER, Dransfield I, Donnelly SC, Strieter R and Haslett C: Extracellular matrix proteins protect small cell lung cancer cells against apoptosis: a mechanism for small cell lung cancer growth and drug resistance in vivo. Nat Med 5: 662-668, 1999.

25. Kawamura T, Endo Y, Yonemura Y, Nojima N, Fujita H, Fujimura T, Obata T, Yamaguchi T and Sasaki T: Significance of integrin alpha2/beta1 in peritoneal dissemination of a human gastric cancer xenograft model. Int J Oncol 18: 809-815, 2001.

26. Fujita S, Watanabe M, Kubota T, Teramoto T and Kitajima M: Alteration of expression in integrin beta 1-subunit correlates with invasion and metastasis in colorectal cancer. Cancer Lett 91: 145-149, 1995.

27. Elliott BE, Ekblom P, Pross H, Niemann A and Rubin K: Antibeta 1 integrin IgG inhibits pulmonary macrometastasis and the size of micrometastases from a murine mammary carcinoma. Cell Commun Adhes 1: 319-332, 1994.

28. Bissell MJ, Weaver VM, Lelievre SA, Wang F, Petersen OW and Schmeichel KL: Tissue structure, nuclear organization, and gene expression in normal and malignant breast. Cancer Res 59: 1757-1764, 1999. 